\title{
Inhibitory effects of tanshinone IIA from Salvia miltiorrhiza Bge on human bladder cancer BIU-87 cells and xenograft in nude mice
}

\author{
Tao HUANG ${ }^{1}$, Xiaokun YANG ${ }^{2}$, Jianlei JI ${ }^{1}$, Qinghai WANG ${ }^{1}$, Hongyang WANG ${ }^{1}$, Zhen DONG $^{1 *}$ (D)
}

\begin{abstract}
The objective of this study was to investigate the inhibitory effects of tanshinone IIA on human bladder cancer BIU-87 cells and the xenograft in nude mice. BIU-87 cells were treated with tanshinone IIA with concentration of $0.5,1,2$ and $4 \mathrm{~g} / \mathrm{L}$. The cell proliferation, cycle and apoptosis were detected. The nude mice with BIU-87 cell xenograft were treated with normal saline (control), 5-fluorouracil (5-FU), 200, 400 and $600 \mathrm{mg} / \mathrm{kg}$ tanshinone IIA, respectively. The animal body weight and growth of tumor were measured. The expressions of B-cell lymphoma-2 (Bcl-2), Caspase-3 and proliferating cell nuclear antigen (PCNA) protein in xenograft were detected. The apoptosis index of cells was determined. Results showed that, tanshinone IIA inhibited the proliferation of BIU-87 cells, promoted their apoptosis, and arrested more cells in $\mathrm{G}_{0} / \mathrm{G}_{1}$ phase. Tanshinone IIA significantly inhibited the growth of xenograft in nude mice and promoted the apoptosis of tumor cells in xenograft. Tanshinone IIA down-regulated Bcl-2 and PCNA expression and up-regulated Caspase-3 expression in xenograft. In conclusion, tanshinone IIA has inhibitory effects on human bladder cancer BIU-87 cells, and can inhibit the BIU-87 cells xenograft in nude mice.
\end{abstract}

Keywords: bladder cancer; tanshinone IIA; BIU-87; xenograft.

Practical Application: This study has provided a theoretical basis for clinical application of tanshinone IIA to treatment of bladder cancer.

\section{Introduction}

Bladder cancer is one of the most common tumors in the urinary system. The incidence of bladder cancer ranks the ninth place in malignant tumors in the world. Seventy to eighty percent of bladder cancer patients are with the superficial bladder cancer, which seriously threatens the people's health and quality of life (Alfred Witjes et al., 2017). At present, the transurethral electrotomy of bladder tumor is used in most bladder cancer cases. In addition, the intravesical chemotherapy is often performed to prevent the recurrence (Matsushima et al., 2002). Tanshinone IIA is the main active ingredient extracted from dried root and rhizome of Salvia miltiorrhiza Bge. It has activity of expanding blood vessels (Liu et al., 2015), anti-atherosclerosis (Fang et al., 2008), scavenging free radical (Wang et al., 2013) and protecting mitochondria (Jin et al., 2013). The in vivo and in vitro studies show that, tanshinone IIA has significant inhibitory effect on breast cancer (Wang et al., 2005), gastric cancer (Xu et al., 2013), colon cancer (Tu et al., 2012), cervical cancer (Munagala et al., 2015) and lung cancer (Chiu \& Su, 2010). This suggests that, tanshinone IIA may have prevention effect on bladder cancer. However, the in vivo and in vitro inhibitory effects of tanshinone IIA on bladder cancer are seldom reported (Chiu et al., 2014; Huang et al., 2017). This study investigated the inhibitory effects of tanshinone IIA on human bladder cancer BIU-87 cells and the xenograft in nude mice, and explored the possible mechanisms. The objective was to provide a theoretical basis for clinical application of tanshinone IIA to treatment of bladder cancer.

\section{Materials and methods}

\subsection{Cell culture}

Human bladder cancer BIU-87 cells (Cell Bank of the Chinese Academy of Sciences, Shanghai, China) were cultured in RPMI 1640 culture medium containing 10\% FBS and $100000 \mathrm{U} / \mathrm{mL}$ penicillin in electric constant temperature incubator $\left(37^{\circ} \mathrm{C}, 5 \% \mathrm{CO}_{2}\right)$. The digestion and passage were performed using routine methods. The cells in logarithmic growth phase were collected for further experiments.

\subsection{Determination of cell proliferation}

Proliferation of BIU-87 cells was determined using methylthiazoletetrazolium (MTT) method. The cells in the logarithmic growth phase with concentration of $1 \times 10^{5} \mathrm{cell} / \mathrm{ml}$ were incubated in 96 -well culture plate, $200 \mu \mathrm{L}$ per well. The cells were divided into 5 groups, 6 wells in each group for each treatment time. After the cell adherence appeared, the original culture medium was removed, and tanshinone IIA (extracted from Salvia miltiorrhiza Bge; purity 98\%; Shaanxi Taiji Huaqing Technology Co., Ltd., Xi'an, China) was added to the well, and the culture medium was added to make the final volume $200 \mu \mathrm{L}$. In these 5 groups, the final tanshinone IIA concentration was $0,0.5,1,2$ and $4 \mathrm{~g} / \mathrm{L}$, respectively. After culture $\left(37^{\circ} \mathrm{C}, 5 \% \mathrm{CO}_{2}\right)$ for 24,48 and $72 \mathrm{~h}$, the culture medium was sucked, respectively, and $20 \mu \mathrm{L} 0.5 \%$ MTT was added, followed by culture for $4 \mathrm{~h}$. The supernatant was discarded. Dimethyl sulfoxide $(150 \mu \mathrm{L})$ 
was added to each well, followed by oscillation for $10 \mathrm{~min}$. The optical density (OD) of cell solution was detected using microplate reader at the wavelength of $490 \mathrm{~nm}$. The inhibition rate on cell proliferation was calculated as follows: inhibition rate $=\left(\mathrm{OD}_{\text {control group }}-\mathrm{OD}_{\text {experimental group }}\right) / \mathrm{OD}_{\text {control group }} \times 100 \%$.

\subsection{Determination of cell apoptosis and cycle}

Flow cytometry analysis was performed to determine the apoptosis and cycle of BIU-87 cells. BIU-87 cells in the logarithmic growth phase with concentration of $1 \times 10^{5} \mathrm{cell} / \mathrm{ml}$ were incubated in 96-well culture plate, $200 \mu \mathrm{L}$ per well. The cells were divided into 5 groups, 6 wells in each group for each treatment time. After culture for $24 \mathrm{~h}$, the medium was sucked off, and tanshinone IIA was added to the well. The final tanshinone IIA concentration of these 5 groups was $0,0.5,1,2$ and $4 \mathrm{~g} / \mathrm{L}$, respectively. The control group was added with culture medium. After culture for $48 \mathrm{~h}$, the culture medium was sucked, followed by centrifugation at $3000 \mathrm{r} / \mathrm{min}$ for $5 \mathrm{~min}$. The cells were washed with phosphate buffer saline for 3 times. Then, $0.5 \mathrm{ml}$ of propidium iodide was added. After dyeing for $30 \mathrm{~min}$, the cell apoptosis and cell cycle were measured using flow cytometer. The procedures were according to the instruction of kits. The percentage of cells in different phases and the apoptosis rate were calculated.

\subsection{Establishment of nude mice xenograft model of BIU-87 cells}

BIU-87 cells in logarithmic growth phase were taken, and the single-cell suspension $\left(2 \times 10^{7}\right.$ cells $\left./ \mathrm{ml}\right)$ was prepared. The right armpit of $\mathrm{BALB} / \mathrm{c}$ nude mice was disinfected using iodine, and then $0.2 \mathrm{ml} \mathrm{BIU-87}$ single-cell suspension was subcutaneously inoculated at the right armpit. The growth of xenograft tumor was observed every day, and the diameter was measured. The whole operation was performed in the aseptic condition. After transplantation, the nude mice were raised in the specefic pathogen free environment. When the diameter of all xenograft tumors was more than $2 \mathrm{~mm}$, the model was considered successfully established.

\subsection{Animal grouping and treatment}

After establishment of BIU-87 cell xenograft model, 30 nude mice were randomly divided into control, $5-\mathrm{FU}, 200 \mathrm{mg} / \mathrm{kg}$ tanshinone IIA, $400 \mathrm{mg} / \mathrm{kg}$ tanshinone IIA and $600 \mathrm{mg} / \mathrm{kg}$ tanshinone IIA group, 6 nude mice in each group. The nude mice in later 4 groups were intraperitoneally injected with $10 \mathrm{mg} / \mathrm{kg}$ 5 -FU, and 200, 400 and $600 \mathrm{mg} / \mathrm{kg}$ tanshinone IIA, respectively. The nude mice in control group were intraperitoneally injected with equal volume of normal saline. The administration was performed once per two days, and was last for 15 days.

\subsection{Determination of nude mice body weight and growth of xenograft tumor}

At the treatment beginning (day 0 ) and on the day 5, 10 and 15 after treatment beginning, the body weight of nude mice was measured using electronic balance. On the day 15 , all nude mice were executed by cervical dislocation, and the tumor block was taken, the maximal and short diameters of the xenograft tumor were measured, and the tumor volume was calculated. The inhibition rate on xenograft was calculated as follows: inhibition rate $(\%)=(1-$ xenograft mass in treatment group / xenograft mass in control group) $\times 100 \%$.

\subsection{Determination of B-cell lymphoma-2, Caspase-3 protein and proliferating cell nuclear antigen expression in tumor tissue}

Paraffin sections of xenograft tumor were prepared. The western blot assays were performed to detect the expression of B-cell lymphoma-2 (Bcl-2), Caspase-3 and proliferating cell nuclear antigen (PCNA) protein in tumor tissue. The procedures were according to the instruction of kits. The primary and secondary antibodies were provided by Santa Cruz Biotechnology, Inc. (CA, USA). $\beta$-actin was used as the internal reference. The relative levels of $\mathrm{Bcl}-2$ and Caspase- 3 protein were presented by the ratio of their optical density to $\beta$-actin.

\subsection{Determination of apoptosis index of tumor cells}

Apoptosis of tumor cells in xenograft was detected by TUNEL, according to the instruction of TUNEL apoptosis kits. The round, multi-lobed or crescent-shaped dark brown or brown granules presented the positive apoptotic cells. Under the high magnification $(\times 400)$, 5 fields of vision were randomly selected. The total number of cells and the number of positive cells of each section were counted. The apoptotic index (AI) was calculated as follows: $\mathrm{AI}=$ (number of positive cells $/$ total number of cells) $\times 100 \%$.

\subsection{Statistical analysis}

Data were presented as mean \pm standard deviation. All statistical analysis was carried out using SPSS 22.0 software (SPSS Inc., Chicago, IL, USA). The difference among different groups was analyzed using one-way analysis of variance followed by Duncan's multiple range test. $\mathrm{P}<0.05$ was considered as statistically significant.

\section{Results}

\subsection{Effects of tanshinone IIA on proliferation of BIU-87 cells}

Tanshinone IIA with all concentrations had the inhibitory effect on proliferation of BIU-87 cells. The inhibitory effect increased with the increase of tanshinone IIA concentration and prolonging of treatment time. There was significant difference of inhibitory rate between each two concentrations from 0.5 to $4 \mathrm{~g} / \mathrm{L}$ at the same treatment time point $(\mathrm{P}<0.05)$. In addition, there was significant difference of inhibitory rate between each two treatment time points with the same concentration from from 1 to $4 \mathrm{~g} / \mathrm{L}(\mathrm{P}<0.05)$ (Figure 1$)$.

\subsection{Effects of tanshinone IIA on apoptosis of BIU-87 cells}

As shown in Figure 2, all concentrations of tanshinone IIA promoted the apoptosis of BIU-87 cells. The apoptosis rate increased with treatment time prolonging and increase of tanshinone IIA concentration. There was significant difference of apoptosis rate between each two concentrations at the same treatment 


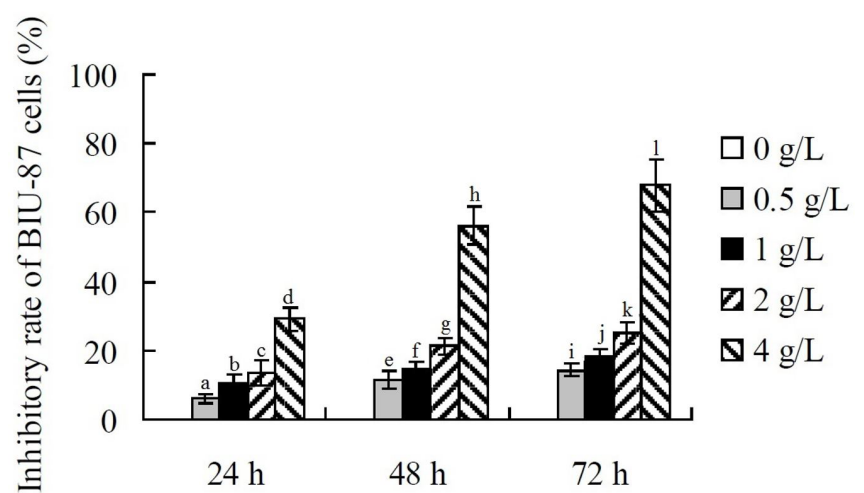

Figure 1. Effects of tanshinone IIA on proliferation of BIU-87 cells $(n=6)$. Different character indicates significant difference.

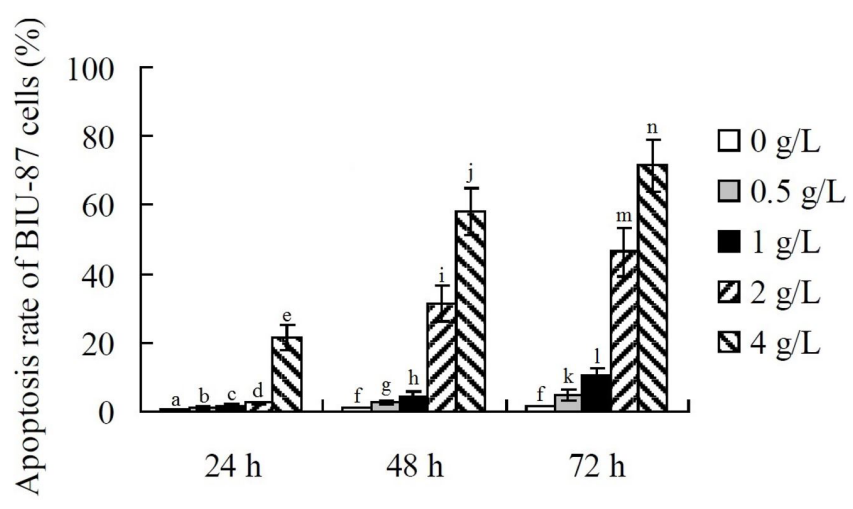

Figure 2. Effects of tanshinone IIA on apoptosis of BIU-87 cells $(n=6)$. Different character indicates significant difference, and the same character means no significant difference.

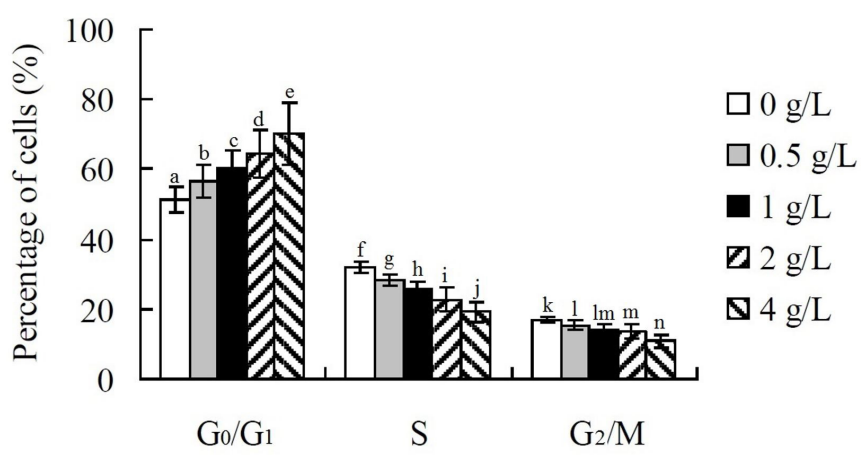

Figure 3. Effects of tanshinone IIA on cycle of BIU-87 cells $(n=6)$. For each phase, different character indicates significant difference, and the same character means no significant difference. time point $(\mathrm{P}<0.05)$, with significant difference between each two treatment time points with the same concentration from 0.5 to $4 \mathrm{~g} / \mathrm{L}(\mathrm{P}<0.05)$.

\subsection{Effects of tanshinone IIA on cycle of BIU-87 cells}

After treatment for $48 \mathrm{~h}$, with the increase of tanshinone IIA concentration, the proportion of cells in phase $\mathrm{G}_{0} / \mathrm{G}_{1}$ increased, and the proportion of cells in phase $S$ and $G_{2} / M$ decreased. There were significant differences of phase $\mathrm{G}_{0} / \mathrm{G}_{1}$ and $\mathrm{S}$ cell proportion between each two tanshinone IIA concentrations from 0 to $4 \mathrm{~g} / \mathrm{L}$, respectively $(\mathrm{P}<0.05)$. In addition, the percentage of cells in phase $\mathrm{G}_{2} / \mathrm{M}$ with tanshinone IIA concentrations from 0.5 to $4 \mathrm{~g} / \mathrm{L}$ was significantly lower than that with tanshinone IIA concentration of $0 \mathrm{~g} / \mathrm{L}(\mathrm{P}<0.05)$ (Figure 3$)$.

\subsection{Effects of tanshinone IIA on body weight of nude mice}

On the day 10 and 15, the body weight in 5-FU group was significantly decreased compared with day 0 and day $5(\mathrm{P}<0.05)$. In addition, the body weight in 5-FU group was significantly lower than that in other 4 groups at day 10 and 15, respectively $(\mathrm{P}<0.05)$. There was no significant difference among other 4 groups at each time point $(\mathrm{P}>0.05)$ (Table 1$)$.

\subsection{Effects of tanshinone IIA on growth of xenograft tumor}

After 15 days of treatment, the xenograft tumor mass and volume in 5-FU and 400 and $600 \mathrm{mg} / \mathrm{kg}$ tanshinone IIA groups were significantly lower than those in control group and $200 \mathrm{mg} / \mathrm{kg}$ tanshinone IIA group, respectively $(\mathrm{P}<0.05)$. The inhibition rate on xenograft in $5-\mathrm{FU}, 50 \mathrm{mg} / \mathrm{kg}$ tanshinone IIA, $100 \mathrm{mg} / \mathrm{kg}$ tanshinone IIA and $200 \mathrm{mg} / \mathrm{kg}$ tanshinone IIA groups were $(42.86 \pm 8.63) \%,(1.69 \pm 0.35) \%,(31.25 \pm 8.44) \%$ and $(48.21 \pm 9.12) \%$, respectively. The inhibition rate in 400 and $600 \mathrm{mg} / \mathrm{kg}$ tanshinone IIA groups had no significant difference with 5-FU group, respectively $(\mathrm{P}>0.05)$ (Table 2$)$.

\subsection{Effects of tanshinone IIA on expression of Bcl-2 and Caspase- 3 protein in tumor tissue}

Relative expression levels of $\mathrm{Bcl}-2$ protein in tumor tissue in 5-FU, $400 \mathrm{mg} / \mathrm{kg}$ tanshinone IIA and $600 \mathrm{mg} / \mathrm{kg}$ tanshinone IIA group were significantly lower than those in control group, respectively $(\mathrm{P}<0.05)$, but that in three tanshinone IIA groups was significantly higher than 5 -FU group, respectively $(\mathrm{P}<0.05)$. The expression levels of Caspase-3 protein in 5 -FU and $600 \mathrm{mg} / \mathrm{kg}$ tanshinone IIA groups were significantly higher than those in control group, respectively $(\mathrm{P}<0.05)$ (Table 3 ).

Table 1. Effects of tanshinone IIA on body weight of nude mice with tumor $(g ; n=6)$.

\begin{tabular}{|c|c|c|c|c|}
\hline Group & Day 0 & Day 5 & Day 10 & Day 15 \\
\hline Control & $17.7 \pm 2.0^{\mathrm{a}}$ & $17.9 \pm 1.4^{\mathrm{a}}$ & $17.8 \pm 1.1^{\mathrm{a}}$ & $18.0 \pm 1.4^{\mathrm{a}}$ \\
\hline $5-\mathrm{FU}$ & $17.7 \pm 1.3^{\mathrm{a}}$ & $16.8 \pm 1.5^{\mathrm{a}}$ & $15.0 \pm 1.4^{\mathrm{b}}$ & $15.1 \pm 1.0^{\mathrm{b}}$ \\
\hline $200 \mathrm{mg} / \mathrm{kg}$ tanshinone IIA & $17.0 \pm 1.1^{\mathrm{a}}$ & $18.5 \pm 1.3^{\mathrm{a}}$ & $19.0 \pm 2.4^{\mathrm{a}}$ & $19.4 \pm 2.6^{\mathrm{a}}$ \\
\hline $400 \mathrm{mg} / \mathrm{kg}$ tanshinone IIA & $17.8 \pm 1.1^{\mathrm{a}}$ & $18.7 \pm 2.3^{\mathrm{a}}$ & $19.0 \pm 2.2^{\mathrm{a}}$ & $19.1 \pm 1.4^{\mathrm{a}}$ \\
\hline $600 \mathrm{mg} / \mathrm{kg}$ tanshinone IIA & $18.5 \pm 1.4^{\mathrm{a}}$ & $17.4 \pm 1.6^{\mathrm{a}}$ & $18.3 \pm 1.3^{\mathrm{a}}$ & $18.6 \pm 1.7^{\mathrm{a}}$ \\
\hline
\end{tabular}

Different character indicates significant difference, and the same character means no significant difference. 
Table 2. Effects of tanshinone IIA on growth of xenograft tumor $(n=6)$.

\begin{tabular}{lccc}
\hline \multicolumn{1}{c}{ Group } & Tumor mass $(\mathrm{g})$ & Tumor volume $\left(\mathrm{cm}^{3}\right)$ & Inhibition rate of tumor $(\%)$ \\
\hline Control & $1.1 \pm 0.3^{\mathrm{a}}$ & $0.7 \pm 0.1^{\mathrm{a}}$ & - \\
5 -FU & $0.6 \pm 0.1^{\mathrm{b}}$ & $0.4 \pm 0.1^{\mathrm{b}}$ & $42.9 \pm 8.6^{\mathrm{a}}$ \\
$200 \mathrm{mg} / \mathrm{kg}$ Tanshinone IIA & $1.1 \pm 0.4^{\mathrm{a}}$ & $0.6 \pm 0.1^{\mathrm{a}}$ & $1.8 \pm 0.4^{\mathrm{b}}$ \\
$400 \mathrm{mg} / \mathrm{kg}$ Tanshinone IIA & $0.8 \pm 0.4^{\mathrm{b}}$ & $0.4 \pm 0.1^{\mathrm{b}}$ & $31.3 \pm 8.4^{\mathrm{a}}$ \\
$600 \mathrm{mg} / \mathrm{kg}$ Tanshinone IIA & $0.6 \pm 0.1^{\mathrm{b}}$ & $0.4 \pm 0.1^{\mathrm{b}}$ & $48.2 \pm 9.1^{\mathrm{a}}$ \\
\hline
\end{tabular}

For each index, different character indicates significant difference, and the same character means no significant difference. 5-FU, 5-fluorouracil.

Table 3. Effects of tanshinone IIA on expressions of Bcl-2 and Caspase- 3 protein in tumor tissue $(\mathrm{n}=6)$.

\begin{tabular}{|c|c|c|}
\hline Group & Bcl- $2 / \beta$-actin & Caspase- $3 / \beta$-actin \\
\hline Control & $0.8 \pm 0.1^{\mathrm{a}}$ & $0.3 \pm 0.0^{\mathrm{a}}$ \\
\hline $5-\mathrm{FU}$ & $0.2 \pm 0.0^{\mathrm{b}}$ & $0.7 \pm 0.1^{b}$ \\
\hline 200 mg/kg Tanshinone IIA & $0.7 \pm 0.1^{\mathrm{c}}$ & $0.3 \pm 0.0^{\mathrm{a}}$ \\
\hline 400 mg/kg Tanshinone IIA & $0.4 \pm 0.1^{\mathrm{d}}$ & $0.3 \pm 0.1^{\mathrm{a}}$ \\
\hline $600 \mathrm{mg} / \mathrm{kg}$ Tanshinone IIA & $0.3 \pm 0.1^{\mathrm{e}}$ & $0.7 \pm 0.1^{\mathrm{b}}$ \\
\hline
\end{tabular}

For each index, different character indicates significant difference, and the same character means no significant difference. 5-FU, 5-fluorouracil; Bcl-2, B-cell lymphoma-2.

Table 4. Effects of tanshinone IIA on expression of PCNA protein in xenograft tumor and AI $(n=6)$.

\begin{tabular}{lcr}
\hline \multicolumn{1}{c}{ Group } & PCNA/ $\beta$-actin & \multicolumn{1}{c}{ AI (\%) } \\
\hline Control & $0.9 \pm 0.1^{\mathrm{a}}$ & $3.9 \pm 0.7^{\mathrm{a}}$ \\
5 -FU & $0.6 \pm 0.1^{\mathrm{b}}$ & $27.2 \pm 4.7^{\mathrm{b}}$ \\
$200 \mathrm{mg} / \mathrm{kg}$ Tanshinone IIA & $0.8 \pm 0.0^{\mathrm{a}}$ & $13.8 \pm 2.1^{\mathrm{c}}$ \\
$400 \mathrm{mg} / \mathrm{kg}$ Tanshinone IIA & $0.6 \pm 0.1^{\mathrm{b}}$ & $21.2 \pm 4.2^{\mathrm{d}}$ \\
$600 \mathrm{mg} / \mathrm{kg}$ Tanshinone IIA & $0.46 \pm 0.0^{\mathrm{c}}$ & $26.45 \pm 3.0^{\mathrm{e}}$ \\
\hline
\end{tabular}

For each index, different character indicates significant difference, and the same character means no significant difference. 5-FU, 5-fluorouracil. 5-FU, 5-fluorouracil; PCNA, proliferating cell nuclear antigen; AI, apoptosis index.

\subsection{Effects of tanshinone IIA on expression of PCNA protein in tumor tissue and AI of tumor cells}

Relative expression levels of PCNA protein in tumor tissue in 5-FU, $400 \mathrm{mg} / \mathrm{kg}$ tanshinone IIA and $600 \mathrm{mg} / \mathrm{kg}$ tanshinone IIA groups were significantly lower than those in control group, respectively $(\mathrm{P}<0.05)$, and that in $600 \mathrm{mg} / \mathrm{kg}$ tanshinone IIA group was significantly lower than 5 -FU group $(\mathrm{P}<0.05)$. The AI of tumor cells 5-FU, 200, 400 and $600 \mathrm{mg} / \mathrm{kg}$ tanshinone IIA groups was significantly higher than that in control group, respectively $(\mathrm{P}<0.05)$ (Table 4$)$.

\section{Discussion}

This study investigated the inhibitory effects of tanshinone IIA on human bladder cancer BIU-87 cells and the xenograft in nude mice. Results showed that, tanshinone IIA with certain concentration inhibited the proliferation of BIU-87 cells, promoted their apoptosis, and arrested more cells in $\mathrm{G}_{0} / \mathrm{G}_{1}$ phase. In addition, tanshinone IIA had no obvious effect on the body weight of nude mice, but significantly inhibited the growth of xenograft in nude mice. This indicates that, tanshinone IIA has in vivo and in vitro inhibitory effects on BIU-87 cells.
The occurrence and development of tumor is a complex process, and it is closely related to the imbalance of cell proliferation, differentiation and apoptosis. The apoptosis of cancerous cells is regulated by a series of genes, and the occurrence and development of tumor are closely related to the blocking of cancerous cell apoptosis (Portt et al., 2011). The Bcl-2 protein family plays a very important role in regulating the apoptosis. High expression of $\mathrm{Bcl}-2$ is often regarded as a protective effect from various apoptotic stimuli (Adams \& Cory, 2007). Therefore, down-regulation of $\mathrm{Bcl}-2$ expression may induce the apoptosis of tumor cells. Cheng \& Su (2010) have investigated the effects of tanshinone IIA on small cell lung cancer H146 cells and find that, tanshinone IIA can down-regulate the expression of Bcl-2 protein, thus induce the apoptosis of H146 cells. In the present study, the relative expression levels of Bcl-2 protein in $400 \mathrm{mg} / \mathrm{kg}$ and $600 \mathrm{mg} / \mathrm{kg}$ tanshinone IIA group were significantly lower than those in control group, respectively $(\mathrm{P}<0.05)$. This indicates that, $\mathrm{Bcl}-2$ is the protective and promoting factor of bladder tumor development. tanshinone IIA can down-regulate the Bcl-2 expression in xenograft tumor, which may be related to its inhibition on growth of xenograft tumor.

Caspase- 3 is a key protein in apoptotic signal conduction pathway. The activated Caspase- 3 can cleave the protein molecules maintaining cell survival. For example, it can degrade the cytoskeleton protein, and decompose the key enzymes for DNA repair. This can cause the cell chromatin condensation ultimately leading to the apoptosis of cell in this signal conduction pathway (Amor et al., 2006). Saegusa et al. (1996) have found that, the expression of Caspase-3 in endometrial carcinomas is positively correlated with the apoptotic index. Sung et al.s research (Sung et al., 1999) has shown that, tanshinone IIA can induce apoptosis of human leukemia cell lines, which has a direct relationship with the activation of Caspase-3 expression. Results of the present study found that, the expression level of Caspase-3 protein $600 \mathrm{mg} / \mathrm{kg}$ tanshinone IIA group was significantly higher than those in control group $(\mathrm{P}<0.05)$. This indicates that, tanshinone IIA can up-regulate the Caspase- 3 expression, thus inhibiting the growth of xenograft tumor and promoting the apoptosis of tumor cells.

PCNA protein is the nuclear protein synthesized in $\mathrm{G}_{1} / \mathrm{S}$ phase of cells, and is the cofactor of DNA polymerase $\delta$. PCNA is involved in the DNA synthesis and cell proliferation, and is widely used in the research of tumor proliferation activity (Gerits et al., 2015). Wang et al. (2015) find that, tanshinone IIA can suppress the expression of PCNA in both prostate epithelial cells and stromal cells, thus effectively preventing the development of the disorder. Results of the present study showed that, the 
expression levels of PCNA protein in $400 \mathrm{mg} / \mathrm{kg}$ tanshinone IIA and $600 \mathrm{mg} / \mathrm{kg}$ tanshinone IIA groups were significantly lower than those in control group, respectively $(\mathrm{P}<0.05)$, and that in $600 \mathrm{mg} / \mathrm{kg}$ tanshinone IIA group was significantly lower than 5 -FU group $(\mathrm{P}<0.05)$. This indicates that, the tanshinone IIA promotion on apoptosis of xenograft tumor may be related to its down-regulation of PCNA expression.

\section{Conclusion}

Tanshinone IIA has inhibitory effects on human bladder cancer BIU-87 cells. In addition, it can inhibit the growth of BIU-87 cell xenograft in nude mice, and promote the apoptosis of tumor cells. The mechanisms may be related to its down-regulation of Bcl-2 and PCNA expression and up-regulation of Caspase-3 expression in tumor tissue. This study has provided the theoretical and experimental basis for the further clinical application of tanshinone IIA treatment of bladder cancer. This study also has some limitations. Firstly, the toxicity test of tanshinone IIA has not performed, so is cannot be concluded that tanshinone IIA has low side effect compared with chemotherapy drugs. The safety of tanshinone IIA needs to be investigated in next studies. Secondly, there may be other mechanisms of tanshinone IIA inhibition on bladder cancer, which should be further investigated.

\section{References}

Adams, J. M., \& Cory, S. (2007). The Bcl-2 apoptotic switch in cancer development and therapy. Oncogene, 26(9), 1324-1337. http://dx.doi. org/10.1038/sj.onc.1210220. PMid:17322918.

Alfred Witjes, J., Lebret, T., Compérat, E. M., Cowan, N. C., De Santis, M., Bruins, H. M., Hernández, V., Espinós, E. L., Dunn, J., Rouanne, M., Neuzillet, Y., Veskimäe, E., van der Heijden, A. G., Gakis, G., \& Ribal, M. J. (2017). Updated 2016 EAU guidelines on muscle-invasive and metastatic bladder cancer. European Urology, 71(3), 462-475. http://dx.doi.org/10.1016/j.eururo.2016.06.020. PMid:27375033.

Amor, N. B., Pariente, J. A., Salido, G. M., Rosado, J. A., \& Bartegi, A. (2006). Thrombin-induced caspases 3 and 9 translocation to the cytoskeleton is independent of changes in cytosolic calcium in human platelets. Blood Cells, Molecules \& Diseases, 36(3), 392-401. http://dx.doi.org/10.1016/j.bcmd.2006.03.002. PMid:16638641.

Cheng, C. Y., \& Su, C. C. (2010). Tanshinone IIA may inhibit the growth of small cell lung cancer $\mathrm{H} 146$ cells by up-regulating the Bax/Bcl-2 ratio and decreasing mitochondrial membrane potential. Molecular Medicine Reports, 3(4), 645-650. PMid:21472292.

Chiu, S. C., Huang, S. Y., Chang, S. F., Chen, S. P., Chen, C. C., Lin, T. H., Liu, H. H., Tsai, T. H., Lee, S. S., Pang, C. Y., \& Hsieh, T. F. (2014). Potential therapeutic roles of tanshinone IIA in human bladder cancer cells. Journal of Molecular Sciences, 15(9), 1562215637. http://dx.doi.org/10.3390/ijms150915622. PMid:25192287.

Chiu, T. L., \& Su, C. C. (2010). Tanshinone IIA induces apoptosis in human lung cancer A549 cells through the induction of reactive oxygen species and decreasing the mitochondrial membrane potential. International Journal of Molecular Medicine, 25(2), 231236. PMid:20043132.

Fang, Z. Y., Lin, R., Yuan, B. X., Yang, G. D., Liu, Y., \& Zhang, H. (2008). Tanshinone IIA downregulates the CD40 expression and decreases MMP-2 activity on atherosclerosis induced by high fatty diet in rabbit. Journal of Ethnopharmacology, 115(2), 217-222. http://dx.doi. org/10.1016/j.jep.2007.09.025. PMid:17997063.
Gerits, N., Johannessen, M., Tümmler, C., Walquist, M., Kostenko, S., Snapkov, I., van Loon, B., Ferrari, E., Hübscher, U., \& Moens, U. (2015). Agnoprotein of polyomavirus BK interacts with proliferating cell nuclear antigen and inhibits DNA replication. Virology Journal, 12(7), 1-14. http://dx.doi.org/10.1186/s12985-014-0220-1. PMid:25638270.

Huang, S. Y., Chang, S. F., Liao, K. F., \& Chiu, S. C. (2017). Tanshinone IIA inhibits epithelial-mesenchymal transition in bladder cancer cells via modulation of STAT3-CCL2 signaling. International Journal of Molecular Sciences, 18(8), 2932-2937. http://dx.doi.org/10.3390/ ijms18081616. PMid:28757590.

Jin, H. J., Xie, X. L., Ye, J. M., \& Li, C. G. (2013). TanshinoneIIA and cryptotanshinone protect against hypoxia-induced mitochondrial apoptosis in H9c2 cells. PLoS One, 8(1), 1-10. http://dx.doi.org/10.1371/ journal.pone.0051720. PMid:23341883.

Liu, X., Guo, C. Y., Ma, X. J., Wu, C. F., Zhang, Y., Sun, M. Y., Pan, Y. T., \& Yin, H. J. (2015). Anti-inflammatory effects of tanshinone IIA on atherosclerostic vessels of ovariectomized ApoE mice are mediated by estrogen receptor activation and through the ERK signaling pathway. Cellular Physiology and Biochemistry, 35(5), 1744-1755. http://dx.doi.org/10.1159/000373986. PMid:25832326.

Matsushima, H., Kawabe, K., Fujime, M., Kitamura, T., Homma, Y., Kishi, H., Kawamura, T., Umeda, T., Ohishi, Y., Murai, M., Kawai, T., Yoshida, H., \& Fukuda, T. (2002). Treatment of patients with superficial bladder cancer by intravesical instillation of anticancer drugs plus oral chemotherapy following TUR-Bt: a randomized controlled trial. Oncology Reports, 9(2), 283-288. http://dx.doi. org/10.3892/or.9.2.283. PMid:11836593.

Munagala, R., Aqil, F., Jeyabalan, J., \& Gupta, R. C. (2015). Tanshinone IIA inhibits viral oncogene expression leading to apoptosis and inhibition of cervical cancer. Cancer Letters, 356(2), 536-546. http:// dx.doi.org/10.1016/j.canlet.2014.09.037. PMid:25304375.

Portt, L., Norman, G., Clapp, C., Greenwood, M., \& Greenwood, M. T. (2011). Anti-apoptosis and cell survival: a review. Biochimica et Biophysica Acta, 1813(1), 238-259. http://dx.doi.org/10.1016/j. bbamcr.2010.10.010. PMid:20969895.

Saegusa, M., Kamata, Y., Isono, M., \& Okayasu, I. (1996). Bcl-2 expression is correlated with a low apoptotic index and associated with progesterone receptor immunoreactivity in endometrial carcinomas. The Journal of Pathology, 180(3), 275-282. http://dx.doi.org/10.1002/ (SICI)1096-9896(199611)180:3<275::AID-PATH660>3.0.CO;2-A. PMid:8958805.

Sung, H. J., Choi, S. M., Yoon, Y., \& An, K. S. (1999). Tanshinone IIA, an ingredient of Salvia miltiorrhiza BUNGE, induces apoptosis in human leukemia cell lines through the activation of caspase-3. Experimental \& Molecular Medicine, 31(4), 174-178. http://dx.doi. org/10.1038/emm.1999.28. PMid:10630370.

Tu, J., Xing, Y., Guo, Y., Tang, F., Guo, L., \& Xi, T. (2012). TanshinoneIIA ameliorates inflammatory microenvironment of colon cancer cells via repression of microRNA-155. International Immunopharmacology, 14(4), 353-361. http://dx.doi.org/10.1016/j.intimp.2012.08.015. PMid:22982040.

Wang, C., Du, X., Yang, R., Liu, J., Xu, D., Shi, J., Chen, L., Shao, R., Fan, G., Gao, X., Tian, G., Zhu, Y., \& Zhang, J. (2015). The prevention and treatment effects of tanshinone IIA on oestrogen/androgeninduced benign prostatic hyperplasia in rats. The Journal of Steroid Biochemistry and Molecular Biology, 145, 28-37. http://dx.doi. org/10.1016/j.jsbmb.2014.09.026. PMid:25290459.

Wang, S., Zang, W., Yang, Y., Zhang, Q., Zhao, M., Gao, Z., Li, G., Meng, Q., Liu, Q., \& Zheng, X. (2013). Tanshinone IIA and Baicalin 
inhibiting the formation of benzo((a))pyrene and benzo((a))pyrene induced cytotoxicity: correlation with scavenging free radical. Environmental Toxicology and Pharmacology, 36(2), 403-410. http:// dx.doi.org/10.1016/j.etap.2013.05.003. PMid:23764461.

Wang, X., Wei, Y., Yuan, S., Liu, G., Lu, Y., Zhang, J., \& Wang, W. (2005). Potential anticancer activity of tanshinone IIA against human breast cancer. International Journal of Cancer, 116(5), 799-807. http:// dx.doi.org/10.1002/ijc.20880. PMid:15849732.

Xu, M., Cao, F. L., Li, N. Y., Liu, Y. Q., Li, Y. P., \& Lv, C. L. (2013). Tanshinone IIA reverses the malignant phenotype of SGC7901 gastric cancer cells. Pacific Journal of Cancer Prevention, 14(1), 173-177. http://dx.doi.org/10.7314/APJCP.2013.14.1.173. PMid:23534719. 